\title{
The Role of Adaptability With The Exigencies of Time and Space in Dynamism OF SHIA JURISPRUdenCE
}

\author{
Morteza Agha-Mohammadi \\ "Urwat al-Wusqa" Research Center, \\ Al-Mustafa International University, Qom, I. R. Iran
}

\begin{abstract}
The ability to adapt to the requirements and exigencies of time and place is a unique feature that distinguishes Shia jurisprudence from many customary jurisprudential schools, and makes it dynamic and capable to last at the same time. It enables the jurists to always find a way out of blocks without being forced to retreat from existing stances. This article aims to discover the role of the exigencies of time and space (place) in the dynamics of Shiite jurisprudence. This research based on library findings, first deals with the necessity of such adaptability, and then a reflection is made on what the concept and function of the role of time and place in jurisprudence is. Finally, dynamic juridical effort (Ijtihad), the necessity of using second order rulings alongside primary ones, mandatory and non-mandatory rulings, governmental rulings, the role of customary understanding, and conflict, are discussed as the key features and components of the dynamic jurisprudence.
\end{abstract}

Keywords: requirements of time and place, dynamic jurisprudence, ijtihad, custom ('urf), Shia jurisprudence, conflict

\section{Introduction}

Human life, as it is situated within time and space, is a fluid and moving phenomenon and does not remain in a single state. On the other hand, any ever-lasting religion has to respond to human needs at all times and places.

Corresponding author: m_aghamohammadi@miu.ac.ir 
Hereon, a question is raised that, since requirements of time and place, and human needs are constantly changing, fixed laws cannot meet the varied and ever-changing needs. In other words, the expansion of primary communities and the creation of urban communities and the change of tribal system and the establishment of modern states require formulation of new laws. Therefore, consideration of the role of the two elements of time and place in jurisprudence is essential in order to conform the Islamic rulings to the newly-occurred requirements.

In the ascending stream of scholarly struggle for accelerating the development of Islamic law and jurisprudence, Shia jurists have taken a special place by suggesting applicable views on its principles, criteria and rules. Although this current was sometimes slow, making its evolutionary process tardy, it was not long before a jurist came to introduce a new diagram to jurisprudence and refresh its dynamism. This stream of refreshment and jurisprudential schooling is due to a number of outstanding jurists, such as Sheikh Tusi, Ibn Idris Hilli, Sahib Jawahar, Sheikh Ansari, Muhammad Baqir Sadr and Imam Khomeini.

\section{The Necessity of Adaptability of Jurisprudence to the Requirements of Time and Place}

There exist notable Hadiths in Islamic literature introducing religious law to be legitimate and permanent until the end of life on earth, like a Hadith from Imam Ja'far bin Muhammad: "The permission and prohibition of Muhammad will last until the Day of Judgment" (Majlisi 1983: XLVII/35). Imam Ali bin Musa says: "It is upon us to tell you the general principles, and it is upon you to deduce detailed rules from them" (Ibn Idris Hilli 2007: III/575). In order to be so, religious rulings must be accordant with the needs and demands of different times and places. This way, they can persist for ever. Many of the rulings in Shiite jurisprudence are flexible in their nature, which can be adapted to different times and places at the same time of enjoying stability and persistence. The ability to adapt to the requirements of time and place is one of the most important features of these rulings.

Shia Islam holds views on both the valuation and the type of attitude towards changes and requirements falling out over time and place, as well as the rulings associated with them. Murtada Mutahari said: "Islam has a very sophisticated legal system that can be synchronized with the developments of the time, but also conductive and directive... Islam is a religion not separate from the law of creation, namely, the legislator of this law is the creator of the world and he has issued it in harmony with creation. 
That is to say, as creation evolves into continuous change, there is also the potential for transformation and dynamism in this legislative system" (Mutahari 1990: 100).

However, it should be noted that not all developments of time and place are favorable and approved by Shia Islam, since some requirements of time and place are based on a cruel, exploitative and ignorant side of human nature. Hence, the Islamic law not only does not comply with these requirements, but it also struggles with them. In contrast, some of the requirements of time and place are due to the advancement and development of life in different cultural, social, industrial, and scientific dimensions. In this case, Shia Islam will identify the positive achievements in these areas and it will issue appropriate rulings. Moreover, when it is said that law of religion is ever-lasting it does not negate changes in the rulings, whether general or specific. As its being inclusive to the rulings man needs does not mean that all the requirements of all times and places are issued in details in the religious law. Hence, it must be noted that any change in the law is not an abrogation and, as it will be explained, rulings of religion can change under specific conditions without being abrogated.

\section{Promoting the Lifestyle Based on the Dynamism of Jurisprudence}

A proper cognition of the dynamism of jurisprudence depends on a profound explanation of its aims and system. The question is whether jurisprudential system should only suffice with organizing the collective and individual life of people and issuing rulings and fatwas without considering the effects of jurisprudence on people's worldly life. The fundamental premise here is the idea that the ultimate prosperity of man counts as the aim of Shia jurisprudence, and the prosperity of this world and the next can be the goal linking the idea of ijtihad to the demands of time and place. Therefore, regardless of the effects of jurisprudential rulings on the worldly life of people, it is not permissible to issue Fatwas. Moreover, if jurisprudence claims to rule and govern human life from cradle to grave (Khomeini 1999: $\mathrm{XXI} / 98$ ), then social justice is the greatest goal that Jurisprudence can follow to govern collective and personal life of human ${ }^{1}$. Thus, a jurist has to think about the effects of fatwas in society and evaluate their relationship with the expansion of social justice.

1 According to Allama Tabatabaei, the reality of religion is modification of human society in the journey of life (Tabatabaei 1997: VI/97). 


\section{Function of Time and Place in Jurisprudence}

According to Mutahari, when the impact of time and place in a jurist's method of Ijtihad is discussed, it means the requirements of time and place. Of course, this does not mean that there are must-be-followed phenomena at all times and places, and that all the newly held phenomena of any time and place demand us to adapt to them, nor does it mean to follow people's tastes that are different at all times, but it implies that the real needs of people change over time and every human need has its requirements. Tools and devices evolve and one must follow them. Islam does not hinder the fulfillment of real needs, but it prevents lustful, satanic whims (Mutahari 1991: II/184, 193-194).

Ayatullah Jafar Subhani, a well-known Shia jurist, considers the meaning of time and place to be metaphoric, that is, the evolution of man's lifestyle and social conditions in terms of the development of time and expansion of communication networks.

Therefore, the requirements of time and place, or in other words, the demands of time and place are conditions created in the realm of time or place and the dynamism of jurisprudence means that there is no deadlock in it and a Muslim person or society facing new issues over time has a strategy to handle them according to true expediencies. Based on Shia teachings, good and evil requirements of time and place are well recognized and proper rulings are issued on the basis of appropriate expediencies and harms. Then, due to scientific, cultural, economic and political changes and social relations, time and place create a situation effective in inferring religious rulings (Feyz 2003: 50). Hence, a jurist, being aware of the developments of time and place, is obliged to respond to the problems and questions resulting from those situations, thereby ensuring the dynamism of jurisprudence in individual and social problems. However, time and place do not affect permanent and fixed rulings governing human relations with God, nature and other people, such as the laws of worship, family system and duty of man towards others. Passage of time does not change these rulings because, for instance, the relation of man with God and the rulings managing this relation do not change or duty of man towards parents does not change, although the form of performance may differ. But, time and place play a major role in parts of cultural, social, political, economic, and medical fields being assigned to human understanding. This is the area that Muhammad Baqir al-Sadr named "zone of permissibility" (Mintaghat al-Firagh) (Sadr 1997: 725). 


\section{Key Characteristics and Components in Dynamic Jurisprudence}

\section{1. Dynamic Ijtihad}

Ijtihad in Shia jurisprudence is to obtain and infer the rulings of various subjects from the Book, traditions (Hadiths), reason, consensus as well as Sharia and rational practical principles. In other words, by appealing to these sources, a jurist seeks to infer divine law on various subjects, not by using arbitrary demands. Before practicing Ijtihad, a jurist, in addition to the standard conditions of Ijtihad, must be well familiar with the rulings of religion and the quality of time and place of the revelation of verses and statement of Hadiths, as well as the causes of divine commandments as much as possible. He has to be capable to distinguish the fixed rulings of religion from those that have been stated due to specific time of the prophet or infallible Imams. He also needs to understand the circumstances of his own time and place and their entailments.

Regarding the inference of rulings, a jurist faces two categories of issues. One set of issues existed at the time of the emergence of Islam, and the prophet and infallible Imams addressed them, and another set of issues are the ones occurring later due to changing conditions and requirements of time and place. Using the four sources of the Quran, traditions, reason, and consensus, as well as inferential principles provided by the Imams, a jurist can infer the divine will for the rulings of various issues. Imam Jafar bin Muhammad says: "There is no disputable issue except that there is a principle for it in the book of God, but it has not struck the human mind" (Kulayni 1987: I/59). All rulings issued must be based on the principles and regulations stated by the Quran and Imams so that the law of God is not altered; no forbidden is permitted nor a permissible is prohibited. This does not mean impossibility of change in divine rulings, but the possibility of change in divine rulings is also one of divine rulings being possible on the basis of certain principles stated by the Quran and Hadiths. This means that divine rulings are based on real expediencies and harms and that a jurist is obliged to infer the divine rulings in the way that the Quran and Hadith have provided him.

Contrary to Asharites, Shia jurists believe that Islamic rulings are subject to real expediencies and harms (Masalih and Mafasid); so if Islam considers something obligatory, it is because there is an interest and expediency in it, and if something is forbidden, it is due to harms existing in it. As a result, if a ruling of something is not stated in the Quran and Sunnah, but reason finds expediency or harm in it, then it issues rulings according to it. Imam Ali ibn Musa al-Rida rejecting the idea that religious rulings are not due to 
true expediency or harm, but merely for the purpose of bringing people to obedience, says: "A person who thinks so has gone astray. Otherwise, if issuing obligations and prohibitions was for mere obedience, then it was permissible to command people to eschew good conducts and beliefs and commit vice, because following such commands was also obedience" (Ibn Babiwayh 1966: II/592).

Explaining the dynamic of Ijtihad, Imam Khomeini considers being particularly most-learned in jurisprudence to be insufficient for handling social issues. He believes that if one is knowledgeable in the field of common jurisprudence studied in seminaries, but fails to recognize interests and expediencies of societyand lacks proper social and political vision and decision-making power, one cannot take religious control of a society (Khomeini 1999: XXI/47).

\section{2. Primary and Secondary Rulings}

The existence of secondary rulings along with primary rulings indicates the flexibility of the jurisprudential system with various states of the duty-bound. Primary rulings are issued for subjects concerning their normal and general state, such as obligation of fasting in the month of Ramadan and prohibition of drinking wine. However, the secondary rulings address a subject in the states of urgency, being forced, and so on, such as the prohibition of fasting in the month of Ramadan for a person to whom fasting causes illness or postpones getting healthy. The reason for naming such rulings as secondary is their being vertical to primary rulings meaning; they are applied when primary rulings cannot be practiced (Meshkini Ardabili 1995: 121). Hence, a primary ruling is issued without regard to states of urgency, fear, incapability, harm, weakness, exception and alike, contrary to the secondary rulings (see: Kalantari 1999; Sadr 1989). In other words, primary rulings of a subject are fixed according to its essence, such as permissibility of eating dates and prohibition of wine, but secondary rulings are due to matters outside the essence, such as the titles of Hardship ${ }^{1}$, Vow ${ }^{2}$, Usurpation $^{3}$ and the like (Hakim 1987: 1, 507).

Hence, one of the most important tools enabling reconciliation with time and place is the existence of secondary rulings alongside primary rulings. For example, the right to divorce is primarily in the hand of the husband, but if a sit-

1 For example, when using water is harmful for a person, instead of performing Wudu for Salat, one has to do dry ablution (Tayammum).

2 For example, fasting is not obligatory in other than the month of Ramadan, however if one vows in a Sharia way to do so, then it becomes obligatory upon him/her.

3 For example, one can perform Salat on any land, but if the area is usurped, Salat cannot be valid there. 
uation arises when the wife is subjected to excessive stress or oppression, the religious ruler can execute a divorce without the consent of the husband. Another example - eating corpse of an animal (that is not slaughtered in a Shari way) is forbidden as a primary ruling, however, if at a particular place or time pure food is not available and one's life depends on eating corpse, not only is it permissible but also obligatory. It should be emphasized that, as it was already mentioned, secondary rulings are vertical to primary rulings, not parallel to them, so as long as obedience to the primary rulings is possible it is not the case for the secondary ones. Moreover, primary rulings are permanent, the secondary ones are temporary; so, as soon as the crying need for them is removed, primary rulings must be applied again. The following are two important secondary rulings.

\section{2. 1. Rule of No-Harm}

According to this rule, any ruling that causes harm to a person or people loses its legitimacy. In other words, according to this rule, Islamic rulings are obligatory when they do not entail any notable harm. For example, performing Salat depends on performing Wudu (ablution) first. However, if using water causes harm to a person, then wudu will be replaced by another act, that is, dry-ablution (Tayammum). Or, it is forbidden for a non-Mahram man to touch the body of a woman or to look at her undressed body, but if a woman's health depends on being touched or looked at by a male physician, then it won't be forbidden in this case. This rule is uttered by the prophet in the story of Samurat bin Jundab, when he was causing harm to his neighbor by misusing a religious law, the prophet said: "To harm oneself or others is removed in Islam" (Kulayni 1987: V/294).

\section{2. 2. The Rule of Negation of Hardship ('Usr and Haraj)}

Based on this rule, any ruling that is intolerable or overburdened loses its religiosity. In addition to reason and consensus, many verses and traditions issue this rule, like: "He has not placed for you any hardship (obstacle) in the religion" (Quran 22: 78). In the above-mentioned example, if water is not harmful for a person, but to provide water for performing ablution puts man in hardship, again $W u d u$ will be replaced by dry-ablution.

\section{3. Mandatory and Non-Mandatory Rulings}

Division of rulings to mandatory rulings (obligation and prohibition) and non-mandatory ones (recommendation, abomination and permissibility) is among the elements forming a dynamic jurisprudence. Jurists can issue 
mandatory rulings in the realm of non-mandatory rulings, on the basis of expediencies that they recognize. For example, an insurance contract is not legally obligatory, however, the jurist can prescribe for social protection that car insurance is required for vehicles. Or, in the case of a woman's blood money, since women are bread-winners of their family in many societies nowadays, jurists can take into account equality of man and woman in the contracts between the insured and the insurer. A jurist can also temporarily prohibit an act whose primary ruling is recommendation, abomination or permissibility, due to harms that the conditions of the time or place dictate. Therefore, the legislator has provided the jurist with issuing mandatory rulings in the realm of non-binding rulings and he can provide the society with its newly occurred needs, giving Shia Islam more ability to adapt at any time and place.

According to Shia jurisprudence, anything beyond obligation, prohibition, recommendation and abomination is considered permissible. Bearing in mind that recommendations and abominations are not mandatory, in a larger sense, they are also counted permissible and man is permitted to practice or abandon them.

Since religious rulings are stated in books, when a new issue occurs and jurists doubt about its ruling, if they do not find any definite and clear proof for counting it obligatory or prohibited, the principle of exemption from any burden and mandatory ruling (the principle is called Bara'a in Arabic) will be practiced. Hence, there is an inherent permissibility for any discovery and invention unless the opposite is proven as the Quran reads: "And, for what your tongues describe, do not utter the lie, (saying) this is lawful and this is unlawful, in order to forge a lie against Allah; surely those who forge the lie against Allah shall not prosper" (Quran 16: 116). In the same way, the Prophet is quoted: "The one who forbids what Allah has permitted is like the one who permits what Allah has prohibited" (Ibn al-Qaysarani 2003: 11). Thus, as no one has the right to permit what Allah has prohibited, likewise no one is allowed to prohibit whatever has been permitted by Him. Accordingly, Shia considers modern breakthroughs such as cloning or artificial insemination to be permissible primarily as long as the opposite is not proven by a definite proof.

\section{4. Governmental Rulings}

Governmental rulings are specific rules that the Islamic ruler imposes for the implementation of primary or secondary rulings, such as the rulings relating to passports, driving licenses. These rulings are issued by a jurist who has the direct or indirect position of governing the Islamic state, or they are issued under his supervision. As already mentioned, governmental 
rulings might deal with implementation of primary rulings such as how to practice Haj pilgrimage for Muslims of the country or defining the first and last day of Ramadan, so that people can begin and end fasting based on that. They can also include practicing secondary rulings. For example, according to notable harm that physicians find in smoking narcotics and also their destructive social, cultural and economic impact, a jurist can issue a secondary ruling for prohibition of using narcotics so that using gets Haram and prohibited from religious perspective. Governmental rulings in this case deal with punishments and fines for selling, buying or using narcotics.

Governmental rulings provide a jurist with a possibility to issue needed rulings on the basis of public interest, maintaining the well-being of society and regulating its affairs, establishing proper relationships among different organizations, as well as with organizations and individuals, on cultural, educational, economic, military, political and other issues (Gorji 1990: II/287).

\section{5. Worships and Non-Worships}

Religious rulings can be categorized into worships (devotional matters) and non-worships (transactions and political issues). In the field of worships, all jurisprudential approaches believe that the criteria of rulings are not and will not be known by man. Therefore, no one can discover their criteria, and if there is any reference to the reason or wisdom of the worships in religious sources, they often state a part of the cause, not the complete cause of the rulings. Hence, there is not a way to abandon a worship or change it when the cause is missing, for example, if it is said that Salat causes tranquility for man's soul, then one cannot reject performing Salat on the basis that he/she does not feel at rest by performing Salat. This is because no one knows the real reason for obligation of Salat, to abandon it when that reason is gone. This stance in regard to worships is so strong that no one rejects it.

However, there is a great deal of divergence in transactions and political rulings, and it can be said that the discovery of criteria in these two categories reinforces the dynamism of the traditional jurisprudence and updates it. Hence, it has been said that religion is submission, but submission is in worships, not in transactions. In the case of transactions, the first principle is that the criterion is clear, and that the method of the early jurists was to seek and discover the criterion, and to develop or limit it in accordance with the requirements of their time and place, and they did not look for Shari declarations in this area. Thus, jurists also can discover the criteria of rulings and issue Fatwas upon them. This way, dynamism of jurisprudence and its efficiency can be guaranteed. 


\section{6. Common Usage/Custom ('Urf), A Key Component of Dynamic Jurisprudence}

One of the most important components in dynamic jurisprudence is the custom of society or the common usage of terms. In other words, subjects of religious rulings are applied to their instances through the customary understanding (Mufid 1992: 794, Hilli 1988: III/712). Observing the verses and Hadiths as well as religious rulings, especially in transactions, demonstrates that the divine law-maker has taken customary standards into account and has assigned rulings in this regard (Mughniyah 1982: 169). In these cases, due to differences in customary understanding from the subjects, the rulings differ. For example, "poor" is someone whose standard of living is lower than that of the general public. This differs in different times and places, meaning that one may be poor in one time or society but in another time or society does not count as being poor. Hence, applying this term on its instances depends on customary cognition of it. Accordingly, this difference is effective in enforcing the obligation to pay zakat to the poor (Sadr 1997: 714). Or, that Prophet Muhammad put zakat on nine things possibly because, at that time, they were basic and popular goods. For that reason, they are not the only subject matter for zakat and at other times and places custom can define subject of zakat in more than these nine things (Haeri 2003: V/21). Or, at the time of the Prophet and subsequent periods the basic needs of people were limited in six items of wheat, barley, dates, raisins, olive oil and oil. These very things have been declared as the instances of hoarding that is prohibited. Hence, hoarding in other than these cases was not considered forbidden, but in recent times, with modern developments, new needs have arisen, consequently, the prohibition of hoarding is definitely not limited to those six things. As another example, as a religious ruling, it is forbidden to sell items with no benefit. One of the examples mentioned in Hadiths for this ruling is selling blood, because it did not have any acceptable benefit in the past. However, today, blood is vital and injecting it can rescue lives. In this case, the subject is changed and what was forbidden to sell turns lawful. Hereon, the fixed religious law that is prohibition of selling useless things has not changed, but blood by finding new usages is out of being useless. The same goes for the ruling concerning the sale of human organs under lawful conditions.

Therefore, customs play a significant role in adapting jurisprudential rulings to the requirements of time and place. Rulings can change because of the change in customs. However, these are Ijtihadi rulings in non-worships while, worships are unchangeable.

The subjects of some fixed unchangeable rulings are customary i.e. custom and common usage define their subject. As a result, as the customary 
perception of something changes, the ruling changes as well, for example gambling is permanently prohibited, but what is considered a gambling instrument is customary. Whether or not playing chess or cards at our time, or in our country, is a gambling tool is a question that the custom of time and place determines. Hence, if it is proven that at the time of the infallible Imams chess was considered to be a type of gambling instrument and forbidden, but in the present time, if it is counted an intellectual exercise in customary perception, it would not be prohibited anymore. This is how religious rulings are permanent (prohibition of gambling) and at the same time they are flexible and change in accordance with time and place. As another example, respecting the guest in Islam is highly recommended, but what act is the instance of respecting guests is determined by custom at any time and place. This is the case in all rulings that their subject is defined by custom, except for those instances prohibited by a clear proof, like serving alcohol to guests when the custom of a country confirms it. Imam Khomeini repeatedly referred to custom in different places in transactions. For example, in his book Al-Bay' (Selling) he introduces custom for identifying subjects of rulings as a right choice (Khomeini n. d.: I/381). He criticizes scholars who have questioned the role of custom in identifying instances of subjects mentioned in religious texts, saying: "Since the law-maker addresses people quite like the way people address each other, there is no other way except the same rational method of referring to conventional way of identifying instances and defining concepts" (Khomeini 2000: I/258). He clearly emphasizes customary usage as the only source to define concepts and instances of religious subjects.

All Shia jurisprudential books are full of references and adherence to custom in defining concepts, instances of rulings and even religious rulings. Therefore, it can be argued that custom has a decisive role in many jurisprudential issues, and it is essential for a jurist to have a proper familiarity with common usage and custom in people's conversations. Also, changing of the custom causes the subjects to change and consequently it changes rulings, but as it was explained, this changing of rulings does not cause change in fixed religious rulings.

\section{7. Conflict/Interference of Proofs (Tazahum)}

Conflict is also one of the issues paving the way for establishing a dynamic jurisprudence. Permanent jurisprudential rulings always conflict with one another in life; for example, the ruling of stoning for a married adulterer who meets all the conditions thereof is one of the constant rulings of Islamic jurisprudence. However, preserving the dignity of Islam and an Islamic state 
is also a must, which is no less important than stoning. Hence, if a jurist, using the principles he holds and considering the expediencies and purposes that Allah Almighty considers in the implementation of the Sharia, has come to the conclusion that the execution of stoning is in conflict with the more important interests of Islam and Islamic states, he can temporarily issue a verdict to abandon stoning.

The distinction between an important and a more important ruling when it does not have social implications is assigned to the discretion of individuals, because their disagreement in the selection of the one with more importance in their personal life does not cause chaos. However, in cases where the recognition of the more important has a social impact, such that, if the diagnosis is left to people, it gets chaotic, Islam has assigned the guardian jurist with recognition of it and he can manage the community by recognizing the more important out of the conflicting rulings.

\section{Conclusion}

The two elements of time and place promote dynamism and eternity of jurisprudence and ignoring them will end in recession of jurisprudence and it will lead to the renewal of literalist and superficial jurisprudence of Kharijits and Akhbaris, which will then cause irreparable damage to jurisprudence and the Islamic world. There are key characteristics in Shia jurisprudence keeping it dynamic. Elements of time and place cause subjects of rulings to change according to existing customary understanding of them and consequently they change the rulings, since the subject of a ruling has a causal role in relation to that ruling. Hence, the impact of time and place in jurisprudence is indirect, meaning, they change rulings by the impact they have on their subjects. Customs or common usage define the new and recent concept of a subject and a change that has occurred.

Secondary rulings can issue new temporary rulings in accordance to the newly-occurred demands and requirements of time and place. In addition, there exist governmental rulings that enable practicing primary and secondary rulings in a way to suit the demands of time and place. The realm of non-mandatory rulings is also an open area for issuing new necessary binding rulings to meet requirements of time and place. Almost all serious instances demanding for change of religious rulings are in the realm of non-worships, where a jurist can issue appropriate ruling in accordance with recent entailments. Social life is the field of conflict of interests, hereon; a jurist by defining the most important one due to real expediencies of people and societies can prefer one ruling and abandon another. All these elements enable a dynamic jurisprudence to meet the 
needs and demands of any time and place at the same time keeping it unchanged and permanent.

Received: April $6^{\text {th }}, 2020$.

Accepted: May $15^{\text {th }}, 2020$.

\section{References}

The Quran.

Feyz, Alireza (2002), Wizhegihaye Ejtehad wa Feghhe Pouya, Tehran, Center for Islamic Sciences.

Gorji, Abu al-Qasim (1990), Maqalate Huquqi, Tehran, Tehran University Publication.

Haeri, Murtada (2003), Mabani al-Ahkam fi Usuli Sharayi al-Islam, Qom, n. p.

Hakim, Muhsin (1987), Haqaiq al-Usul, Qom, n. p.

Hilli, Ja'far ibn Hasan (1988), Sharayi al-Islam fi Masail al-Halal wa al-Haram, Qom, Amir.

Ibn Babiwayh, Muhammad ibn Ali (1966), Ilal al-Sharayi', Tehran, Dawari Publication.

Ibn al-Qaysarani, Muhammad ibn Tahir (2003), Kitab al-Sama', Cairo, Ministry of Awghaf.

Ibn Idris Hilli, Muhammad ibn Ahmad (2007), Al-Sarair al-Hawi Li Tahrir al-Fatawa, Qom, Nashre Islami Publication.

Kalantari, Ali Akbar (1999), Hokme Thanawi dar Tashrie Eslami, Qom, Daftare Tablighate Islami.

Khomeini, Ruhullah (n. d.), Al-Bay', Tehran, Institute for Compilation and Publication of Imam Khomeini's work.

Khomeini, Ruhullah (1999), Sahifeye Noor, Tehran, The Organization of Cultural Documents of the Islamic Republic.

Khomeini, Ruhullah (2000), Tahrir al-Wasilah, Qom, Dar al-Ilm.

Kulayni, Muhammad ibn Ya’qub (1987), Usul al-Kafi, Tehran, Dar al-Kutub al-Islamiyyah.

Majlisi, Muhammad Baqir (1983), Bihar al-Anwar, Tehran, Dar Al-Kutub al-Islamiyah.

Meshkini Ardabili, Ali (1995), Istilahat al-Usul wa Mu'zamu Abhathiha, Qom, n. p. Mughniyah, Muhammad Jawad (1982), Al-Figh ala al-Mazahib al-Khamsa, Beirut, n. p.

Mufid, Muhammad ibn Nu'man (1992), Al-Muqnia, Qom, Sheikh Mufid International Conference. 
Mutahari, Murtada (1990), Nezame Hoquqe Zan Dar Eslam, Tehran, Sadra Publication.

Mutahari, Murtada (1991), Eslam wa Moqtaziyate Zaman wa Makan, Tehran, Sadra Publication.

Sadr, Muhammad Baqir (1989), Durusun Fi Ilm al-Usul, Beirut, Dar al-Ta'aruf Lil-Matbu'at.

Sadr, Muhammad Baqir (1997), Iqtisaduna, Beirut, Maktab al-A'lam al-Islami.

Tabatabaei, Muhammad Hussain (1997), Tafsir al-Mizan, Qom, Jami’a Mudarrisin Publication. 


\title{
Značaj uvažavanja zahteva vremena i mesta u šiitskoj jurisprudenciji
}

\author{
Morteza Aga-Mohamadi \\ Istraživački centar „Urvat al-vuska”, \\ Internacionalni univerzitet al-Mustafa, Kom, Iran
}

Mogućnost da bude usklađena sa zahtevima i nužnim potrebama vremena i mesta predstavlja posebno obeležje koje odlikuje šiitsku jurisprudenciju u poređenju s nekim drugim popularnim pravnim školama i, zbog toga, ova škola jurisprudencije ima svoj dinamični istorijski kontinuitet. Pravnici u okviru ove škole lakše prevazilaze prepreke, bez toga da odustanu od svojih principijelnih stavova. Cilj ovog rada jeste da otkrijemo nužni značaj faktora vremena i mesta u dinamičnom razvoju šitske jurisprudencije. $U$ ovom istraživanju, zasnovanom na analizi sadržaja bibliotečke građe, najpre se bavimo nužnošću uvažavanja promenljivih zahteva vremena i mesta i nakon toga analiziraćemo pojam i funkciju promenljivih zahteva vremena i mesta $\mathrm{u}$ jurisprudenciji. Konačno, ekspertsku kreativnost u islamskoj jurisprudenciji, poznatu kao idžtihad, nužnost korišćenja sekundarnih sudova i sudova na temelju autoritativnosti vlasti, uz uvažavanje kredibiliteta primarnih i obaveznih sudova, te najzad model razumevanja običaja u sudovima, razmatraćemo kao ključne odlike dinamične prirode jurisprudencije u islamu.

Ključne reči: zahtevi vremena i mesta, dinamika jurisprudencije, idžtihad, običaji, šitska jurisprudencija, sudovi 